\title{
Change Detection of Benthic Habitat Communities using Landsat Imageries in Wakatobi Islands from 1990 to 2017
}

\author{
Muhammad Hafizt ${ }^{1 *}$, Novi Susetyo Adi ${ }^{2}$, Pramaditya Wicaksono ${ }^{3}$, Doddy Mendro Yuwono ${ }^{4}$, Bayu Prayudha ${ }^{1}$ and Suyarso ${ }^{1}$ \\ ${ }^{1}$ Research Center for Oceanography, Indonesian Research and Innovation Agency, ${ }^{2}$ Marine Research Center, Ministry of Marine Affairs and \\ Fisheries, Indonesia, ${ }^{3}$ Faculty of Geography, Universitas Gadjah Mada, Indonesia, ${ }^{4}$ Geospatial Information Agency, Indonesia
}

Received: 2019-11-23 Accepted: 2021-12-24

Keywords:

Benthic Habitat;

Change Detection Model;

Landsat image;

Wakatobi islands

Correspondent email: muha169@lipi.go.id
Abstract Currently, coral reef and seagrass ecosystems in Wakatobi Islands are categorized as 'poor' because the coverage of the healthy coral is less than $50 \%$. Therefore, detailed information about their condition through time is needed to prevent coastal degradation. Time-series analysis of Landsat images recorded in 1990, 2000, 2010, and 2017 is expected to provide information on coral reefs' habitat in Wakatobi Islands over the studied period. This study aims to determine areas that experience drastic changes in benthic habitat cover and analyze the dynamics of the changes. The image processing procedures used in this study are image correction, image classification, and applying the Change Detection Model. The image correction consists of geometric, sunglint, and water column correction, while the change detection model uses SPEAR Tools in ENVI software. The results showed a precise location that experienced a drastic change in benthic habitat cover and the changes in benthic habitat classes every ten years, which started from 1990 to 2017.

2021 by the authors. Licensee Indonesian Journal of Geography, Indonesia.

This article is an open access article distributed under the terms and conditions of the Creative Commons

Attribution(CC BY NC) licensehttps///creativecommons.org/licenses/by-nc/40/

\section{Introduction}

In Southeast Sulawesi, Indonesia, Wakatobi islands have an extensive coastal area covering coral reef and seagrass ecosystems. The islands, located in the heart of the Coral Triangle, were established as Marine National Park in 1996 and had 1.390 .000 hectares of the conservation area (DJPRL KKP \& Direktorat PRL-KKP, 2012). The islands provide significant values for marine diversity and economic to support coastal communities, becoming an essential local income for the region. However, even though located in a remote location, the status of coral reefs in the area was classified only as 'sufficient' in 2017 (Giyanto et al., 2017) and then dropped into 'poor' in 2018 (Hadi et al., 2018). The unsatisfactory status also occurs for seagrass classified as 'unhealthy' in 2017 (Hernawan et al., 2017) and 2018 (Sjafrie et al., 2018), meaning the average live coral and seagrass cover on Wakatobi Island were less than 50 percent in 2017 and 2018 .

Regarding the status of the two essential coastal ecosystems, the coastal area needs conservation efforts to improve coral reef and seagrass conditions (Nybakken \& Eidman, 1988). At the same time, remote sensing technology can provide time-series data that can be used to study the change of benthic habitat cover from the past to the present. Moreover, remote sensing technology is cost-effective and time-efficient in providing synoptic information and facilitating spatial analysis for extensive and remote area mapping (Goodman et al., 2013; Muhammad Hafizt et al., 2017; Joyce et al., 2004; Lyons et al., 2011; Manessa et al., 2014; Wicaksono, 2016) that makes it possible to produce a good-quality reef habitat map (Green et al., 2000). In addition, the moderate spatial resolution satellite imageries like Landsat have recorded data since 1972 (U.S. Department of the Interior, 2019), which also makes it potential to use for change detection analysis of benthic habitat (Yasir Haya \& Fujii, 2017). However, it is still scarce (Goodman et al., 2013) and challenging to conduct change detection studies due to different illumination conditions and water column differences between all imagery used (Purkis \& Klemas, 2011).

This study aims to identify areas that underwent benthic cover changes in Wakatobi islands using multi-temporal Landsat images and assess the dynamics of the changes, particularly for coral reef and seagrass cover inside the changed areas. Landsat satellite imagery recorded since the '80s makes it suitable for long-term time-series analysis for Wakatobi islands located in rather a remote area where a comprehensive field campaign would be logistically challenging. The results of this study are expected to contribute to government and stakeholders in planning and optimizing conservation programs so human activities conducted in the coral reef and seagrass ecosystem can be managed sustainably. In addition, the result of the study can be used to complete information on coral reef and seagrass status in Indonesia, especially in the Wakatobi islands.

\section{The Methods}

The procedure used in this research is divided into image correction and field survey methods. Image correction consists of sequential processing to minimize errors on the image before it is classified and used in the change detection model (Green et al., 2000). The processing categories of the image correction method are shown in Figure 1, which is initiated by applying image correction consisting of geometric, sunglint, and water column corrections. 
Atmospheric correction using the Dark Object Subtraction (DOS) method was not applied in this study as it produced negative pixel values in very shallow and exposed areas during low tide, where seagrass with high-density cover may be present. Moreover, the sunglint correction was assumed to automatically reduce the atmospherical effect due to the minimum values of a near-infrared band used in its equation (Anggoro et al., 2016; Goodman et al., 2013; Kay et al., 2009).

The primary data used were Landsat time-series images from 1990, 2000, 2010, and 2017, where every 10-year image acquisition is expected to show the contrast changes in coral reef cover and seagrass beds. For map accuracy, assessment samples collected in 2015 and 2016 were used, and it was assumed that those data can still represent field conditions in 2017. With visible bands (red, green, and blue) and moderate spatial resolution (30 meters), the Landsat image is suitable to accommodate the high diversity of benthic habitat covers in an extensive area such as the Wakatobi islands. From Table 1 below, we can see that all images used have scene-specific characteristics, which makes image correction is essential to conduct multi-temporal analysis.
According to Figure 1, the image correction step consists of geometric correction (Danoedoro, 2012), Sunglint correction (Kay et al., 2009), and water column corrections. The geometric correction repositions an image according to a georeferenced image provided as a base map. For example, the geometric correction used the image-to-image method with Landsat 8 (2017) as the reference to geometrically correct Landsat 5 images of 1990 and 2010. However, the geometric correction was not applied on Landsat 7 as the satellite image has already matched geometrically with Landsat 8 . The result of the geometric correction was then continued with Sunglint and Water Column corrections, where pixel values extracted from a region of interest (ROI) are required to implement the equation as shown in Table 2 and Table 3. Water column correction is implemented using the Depth Invariant index (DII) model (Green et al., 2000).

The next image processing steps are image masking ( $M$. Hafizt et al., 2017) and image classification. The masking process is essential to restrict and optimize the classification result only in shallow water areas with a great variety of benthic habitats. The masking process is applied using the

Table 1. Detail information of Landsat imageries used in this research

\begin{tabular}{|c|c|c|c|c|}
\hline Characteristic & 1990 & 2000 & 2010 & 2017 \\
\hline SPACECRAFT_ID & LANDSAT_5(L5) & LANDSAT_7 (L7) & LANDSAT_5(L5) & LANDSAT_8(L8) \\
\hline Landsat scene id & $\begin{array}{l}\text { LT51110641990289 } \\
\text { ASA00 }\end{array}$ & $\begin{array}{l}\text { LE71110642000309ASA } \\
00\end{array}$ & $\begin{array}{l}\text { LT51110642011027ASA } \\
00\end{array}$ & $\begin{array}{l}\text { LC81110642017347LGN } \\
00\end{array}$ \\
\hline Data acquired & $\begin{array}{l}\text { 1990-10-16 } \\
\text { (transition season) }\end{array}$ & $\begin{array}{l}2000-11-04 \quad \text { (transition } \\
\text { season) }\end{array}$ & $\begin{array}{l}\text { 2011-01-27 (west wind } \\
\text { season) }\end{array}$ & $\begin{array}{l}\text { 2017-12-13 (west wind } \\
\text { season) }\end{array}$ \\
\hline Data Type & L1GS & L1TP & L1GS & L1TP \\
\hline Sensor ID & TM & ETM+ & $\mathrm{TM}$ & OLI_TIRS \\
\hline Path/row & $111 / 064$ & $111 / 064$ & $111 / 064$ & $111 / 064$ \\
\hline \multirow{8}{*}{$\begin{array}{l}\text { Band } \\
(\mu \mathrm{m})\end{array}$} & Blue band (B1): & Blue band (B1): & Blue band (B1): & Blue band (B2): \\
\hline & $0.45-0.52$ & $0.45-0.52$ & $0.45-0.52$ & $0.45-0.51$ \\
\hline & Green band (B2): & Green band (B2): & Green band (B2): & Green band (B3): \\
\hline & $0.52-0.60$ & $0.52-0.60$ & $0.52-0.60$ & $0.53-0.59$ \\
\hline & Red band (B3): & Red band (B3): & Red band (B3): & Red band (B4): \\
\hline & $0.63-0.69$ & $0.63-0.69$ & $0.63-0.69$ & $0.64-0.67$ \\
\hline & NIR band (B4): & NIR band (B4): & NIR band (B4): & NIR band (B5): \\
\hline & $0.76-0.90$ & $0.77-0.90$ & $0.76-0.90$ & $0.85-0.88$ \\
\hline
\end{tabular}

Source: U.S. Geological Survey (LSDS-1574 V1, 2015; USGS, 1879)

Table 2. list of parameters from every image used to create the sunglint equations

\begin{tabular}{|c|c|c|c|c|}
\hline Parameters & 1990 (L5) & 2000 (L7) & 2010 (L5) & 2017 (L8) \\
\hline Number of ROI & 1109 sample & 1814 sample & 954 sample & 3088 sample \\
\hline Minimum NIR & 49 & 1 & 5 & 21 \\
\hline $\mathrm{R}^{2}$ Blue - NIR & 0.7910 & 0.9891 & 0.7488 & 0.6569 \\
\hline $\mathrm{R}^{2}$ Green - NIR & 0.9461 & 0.9917 & 0.9150 & 0.9928 \\
\hline $\mathrm{R}^{2}$ Red - NIR & 0.9560 & 0.9905 & 0.9606 & 0.9972 \\
\hline \multirow[t]{3}{*}{ Sunglint equations } & B1- $\left(0.513^{*}(\mathrm{~B} 4-49)\right)$ & $\mathrm{B} 1-\left(0.827^{\star}(\mathrm{B} 4-1)\right)$ & $\mathrm{B} 1-\left(0.628^{\star}(\mathrm{B} 4-5)\right)$ & B2- $\left(0.381^{\star}(\mathrm{B} 5-21)\right)$ \\
\hline & B2- $\left(0.834^{*}(\mathrm{~B} 4-49)\right)$ & B2- $\left(0.926^{\star}(B 4-1)\right)$ & B2- $\left(0.872^{*}(\mathrm{~B} 4-5)\right)$ & B3- $\left(0.734^{\star}(\mathrm{B} 5-21)\right)$ \\
\hline & B3- $\left(0.957^{\star}(\mathrm{B} 4-49)\right)$ & B3- $\left(1.017^{\star}(\mathrm{B} 4-1)\right)$ & B3- $\left(0.924^{\star}(\mathrm{B} 4-5)\right)$ & B4- $\left(0.886^{\star}(\mathrm{B} 5-21)\right)$ \\
\hline
\end{tabular}

Table 3. Equations of the water column correction for each band in every image and the total ROI sample used to create that equations.

\begin{tabular}{|c|c|c|c|}
\hline Number of ROI & Bblue/Bgreen & Bblue/Bred & Bgreen/Bred \\
\hline 1990 (L5): 38 ROI sample & $(\operatorname{alog}(\mathrm{B} 1))-\left(0.591^{\star}(\operatorname{alog}(\mathrm{B} 2))\right)$ & $(\mathrm{a} \log (\mathrm{B} 1))-\left(0.332^{\star}(\mathrm{a} \log (\mathrm{B} 3))\right)$ & $(\mathrm{a} \log (\mathrm{B} 2))-\left(0.572^{\star}(\mathrm{a} \log (\mathrm{B} 3))\right)$ \\
\hline 2000 (L7): 109 ROI sample & $(\operatorname{alog}(\mathrm{B} 1))-\left(0.572^{\star}(\operatorname{alog}(\mathrm{B} 2))\right)$ & $(\operatorname{alog}(\mathrm{B} 1))-\left(0.236^{*}(\mathrm{a} \log (\mathrm{B} 3))\right)$ & $(\mathrm{alog}(\mathrm{B} 2))-\left(0.424^{\star}(\mathrm{a} \log (\mathrm{B} 3))\right)$ \\
\hline 2010 (L5): 102 ROI sample & $(\operatorname{alog}(\mathrm{B} 1))-\left(0.613^{*}(\operatorname{alog}(\mathrm{B} 2))\right)$ & $(\operatorname{alog}(\mathrm{B} 1))-\left(0.221^{*}(\operatorname{alog}(\mathrm{B} 3))\right)$ & $(\operatorname{alog}(\mathrm{B} 2))-\left(0.404^{*}(\operatorname{alog}(\mathrm{B} 3))\right)$ \\
\hline 2017 (L8): 83 ROI sample & $(\operatorname{alog}(\mathrm{B} 2))-\left(0.520^{\star}(\operatorname{alog}(\mathrm{B} 3))\right)$ & $(\mathrm{a} \log (\mathrm{B} 2))-\left(0.292^{\star}(\operatorname{alog}(\mathrm{B} 4))\right)$ & $(\mathrm{a} \log (\mathrm{B} 3))-\left(0.587^{\star}(\operatorname{alog}(\mathrm{B} 4))\right)$ \\
\hline
\end{tabular}


Relative Water depth Index (RWDI) model (M. Hafizt et al., 2017) or by adding the Near-Infrared band and the Quality Assessment (QA) as optional parameters. A single mask template was created by determining threshold values that only cover shallow water areas in all images used, then applied to all images used before the classification process.

Image classification was applied using the ISO-DATA algorithm to represent various benthic habitat covers in the field (Muhammad Hafizt et al., 2017). The ISO-DATA algorithm is robust and flexible to accommodate the classification parameters applied for this study (Green et al., 2000; M. Hafizt et al., 2017). Moreover, it has a sufficient statistical equation that can minimize the misclassification of each image used. The ISO-DATA classification algorithm was applied to all water column corrected images. All field samples collected in 2015, 2016, and 2017 were used to calculate the map accuracy. The ISO-DATA algorithm was applied using parameters of five classes for the minimum number of categories, ten times for iteration, and $2 \%$ for the change threshold value.

The last step was calculating map accuracy by using a confusion matrix table. The table will provide the Overall Accuracy (OA), User Accuracy (UA), Producer Accuracy (PA), Error Omission (EO), and Error Commission (EC) required to assess the resulting benthic maps (M. Hafizt et al., 2017; Muhammad Hafizt \& Danoedoro, 2015). The accuracy assessment only applies to 2017's benthic habitat map, as it is the closest acquisition time to the field works. As long as the overall accuracy is over 60\% (Badan Informasi Geospatial, 2014), the process is continued to change cover analysis using ENVI software's Change Detection Model (CDM) from the SPEAR Tool function.

The change Detection Model (CDM) is commonly used in terrestrial analysis and has succeeded in detecting houses and residential street networks (Unsalan \& Boyer, 2004). A similar characteristic is also found in the coastal area, particularly in the shallow water zone, with a consistent water depth (0-1 m below sea level) and periodically exposed to tides. The zone is mainly occupied by seagrass cover that correlates with Normalized Difference Vegetation Index (NDVI) provided in the CDM. The resulted model was new subtractive bands showing the relative change of the shallow water area, which was then classified using the ISO-DATA algorithm to obtain specific benthic habitat classes representing the most significant changes. The last process was overlaying all classification results to identify changes every ten years from 1990 to 2017.

Field samples were collected using the photo transect method (Roelfsema \& Phinn, 2009) and direct visual identification in the field, known as the Stop and Go method (Prayudha, 2014). The field types of equipment used for sample collection were a Global Positioning System (GPS) Garmin eTrex 30 for recording sample positions and a GoPro HERO 4 underwater camera for recording photos of the benthic type. Field samples collection started from the main island of Wakatobi and its surrounding islands, including Wangi-Wangi Island, Kaledupa Island, Tomia Island, Binongko Island, Kapota Reef and Kaledupa Reef. The coverage of study area can be shown in Figure 2.

\section{Result and Discussion}

The results consisted of field data and information on benthic habitat change from time-series map analysis. The total field sample used was 886 , consisting of samples taken in 2015 and 2016 using direct visual observation and in 2017 using the photo transect method (Figure 3). Because of the

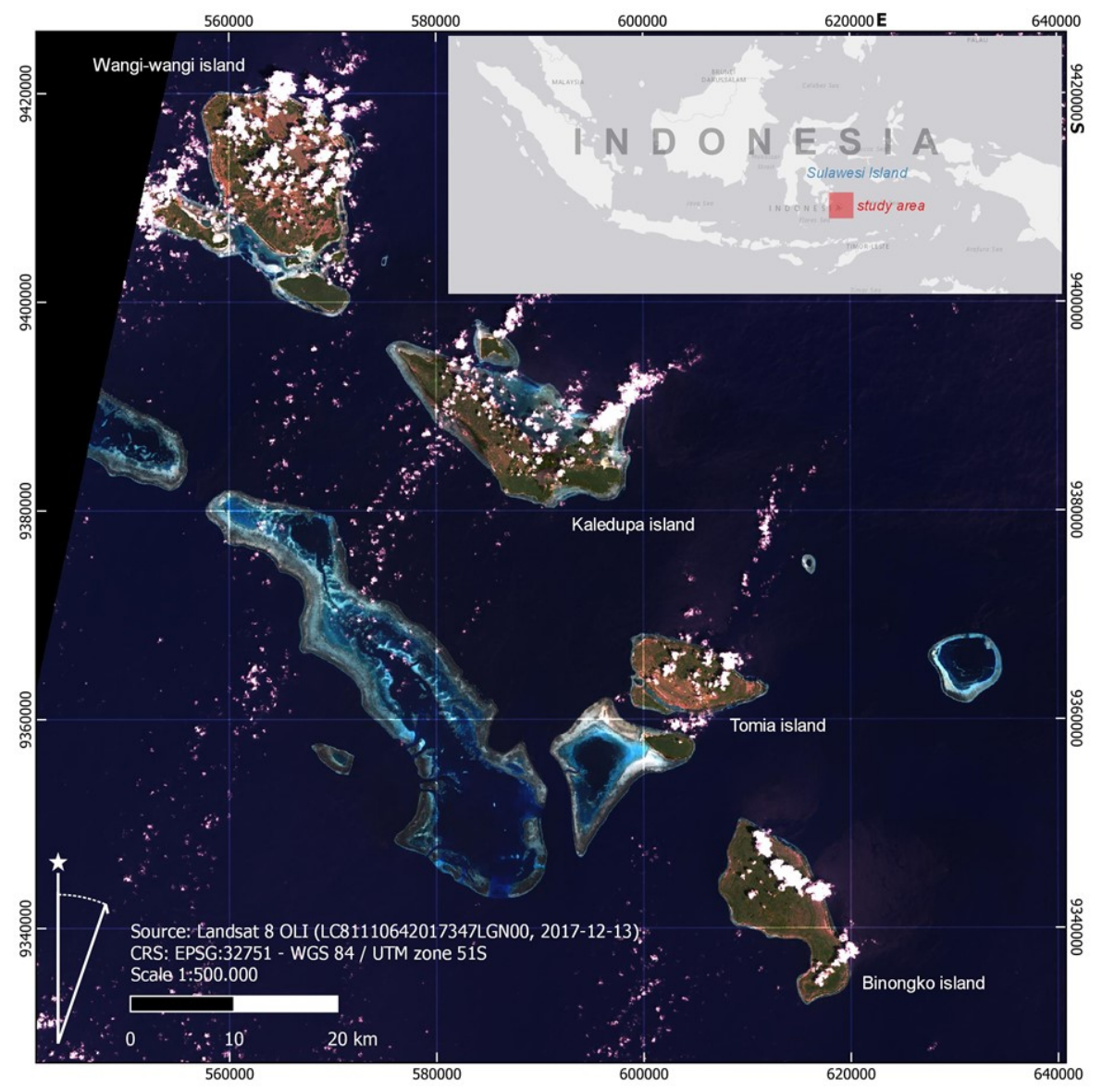

Figure 2. study area in Wakatobi Islands, Southeast Sulawesi, Indonesia 
classification scheme differences on both sample groups, standardization was needed by creating a new classification scheme based on field samples taken in 2017. The reason is that the 2017's field sample is supplemented with photos of bottom objects for each sample point. The 2017 photo sample is then used as a base for the new classification scheme representing the variations of benthic habitat cover in Wakatobi islands. The remaining field samples taken in 2015 and 2016 were adjusted to follow 2017's classification system, as depicted in Figure 3. This classification scheme became the reference to determine the number of classes in the image classification step. Finally, the entire 886 samples were used to calculate the accuracy of the benthic habitat map as the image classification process using the ISO-DATA method does not require a sample reference.

The final classification scheme consisted of five benthic habitat classes based on each photo's visual interpretation of benthic types. Naming the class of benthic habitat cover was done by modifying the classification system of previous research (NOAA, 2005; Zitello et al., 2009) to represent Indonesia's benthic habitat cover which was relatively dominated by the five classes. The five classes of the benthic habitat consist classes of a full cover of seagrass (SG), a sparse cover of seagrass that mix to another substrate (SGMIX), a full cover of coral reef on photo sample (HC), bare substratum class (consisting of sand, rubble, rock or mix each other (MBR) and a full cover of sand (SD). The photos of the final benthic habitat scheme can be seen in Figure 4 .

On the other hand, ISO-DATA classification produced four benthic habitat maps (Figure5) with a total of 5 classes, each consisting of Class 1 to 5 . The number of classes followed the number of benthic habitat classes in Figure 5, and the names of ISO DATA classes correspond to benthic habitat classes in Figure 4. Renaming the ISO-DATA classes was done through visual interpretation using the interpretation keys and professional justification (Green et al., 2000). In the final map, class 1 was classified as seagrass cover (SG), Class 2 as mix seagrass cover (SGMIX), Class 3 as hard coral (HC) cover, Class 4 as mix hard coral cover (MBR), and Class 5 as sand cover (SD). From the benthic habitat maps in Figure 5, seagrass cover in the dark green has decreased from 1990 to 2017. The accuracy of the benthic habitat map was then performed using a confusion matrix table.

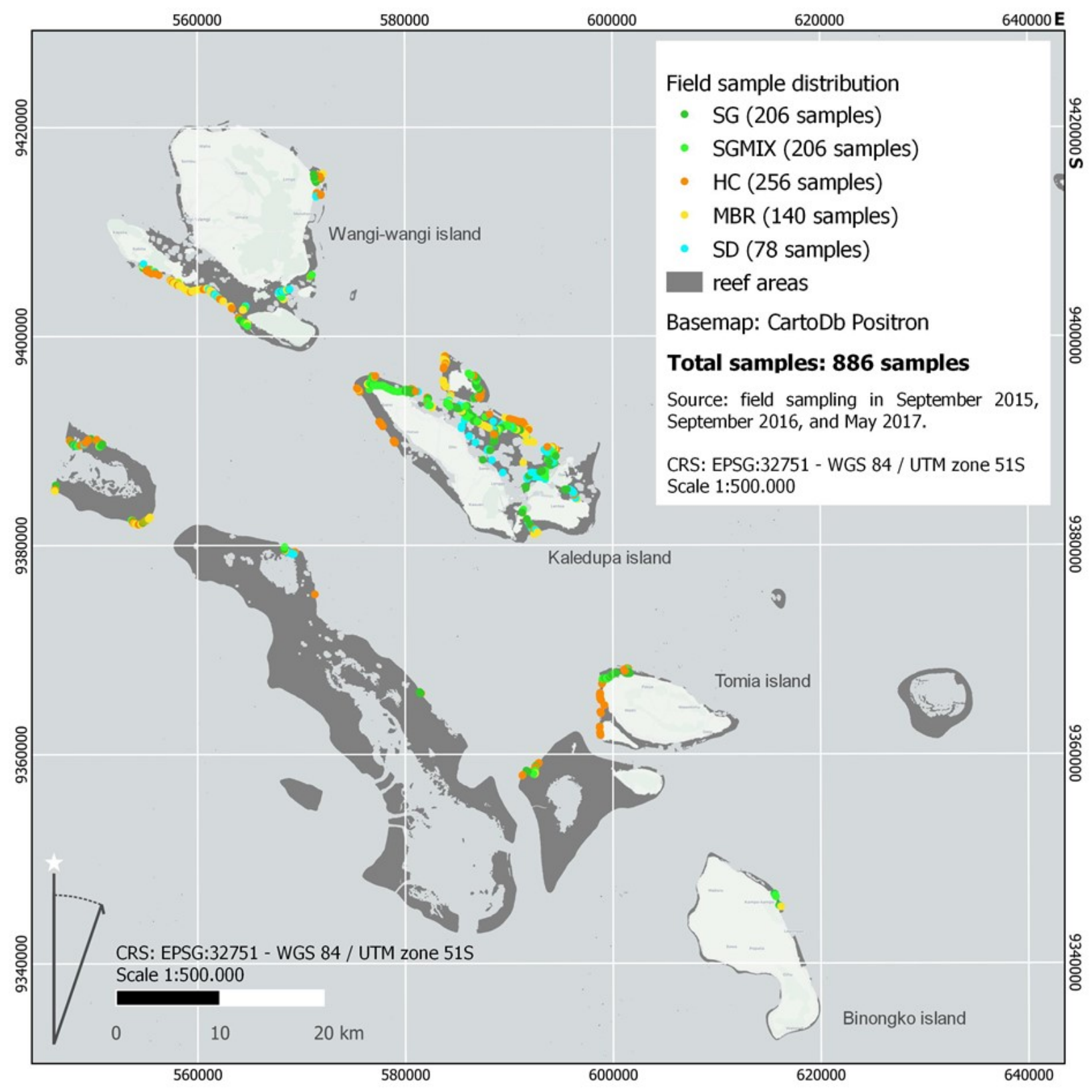

Figure 3. field sample distribution and number of samples per class 


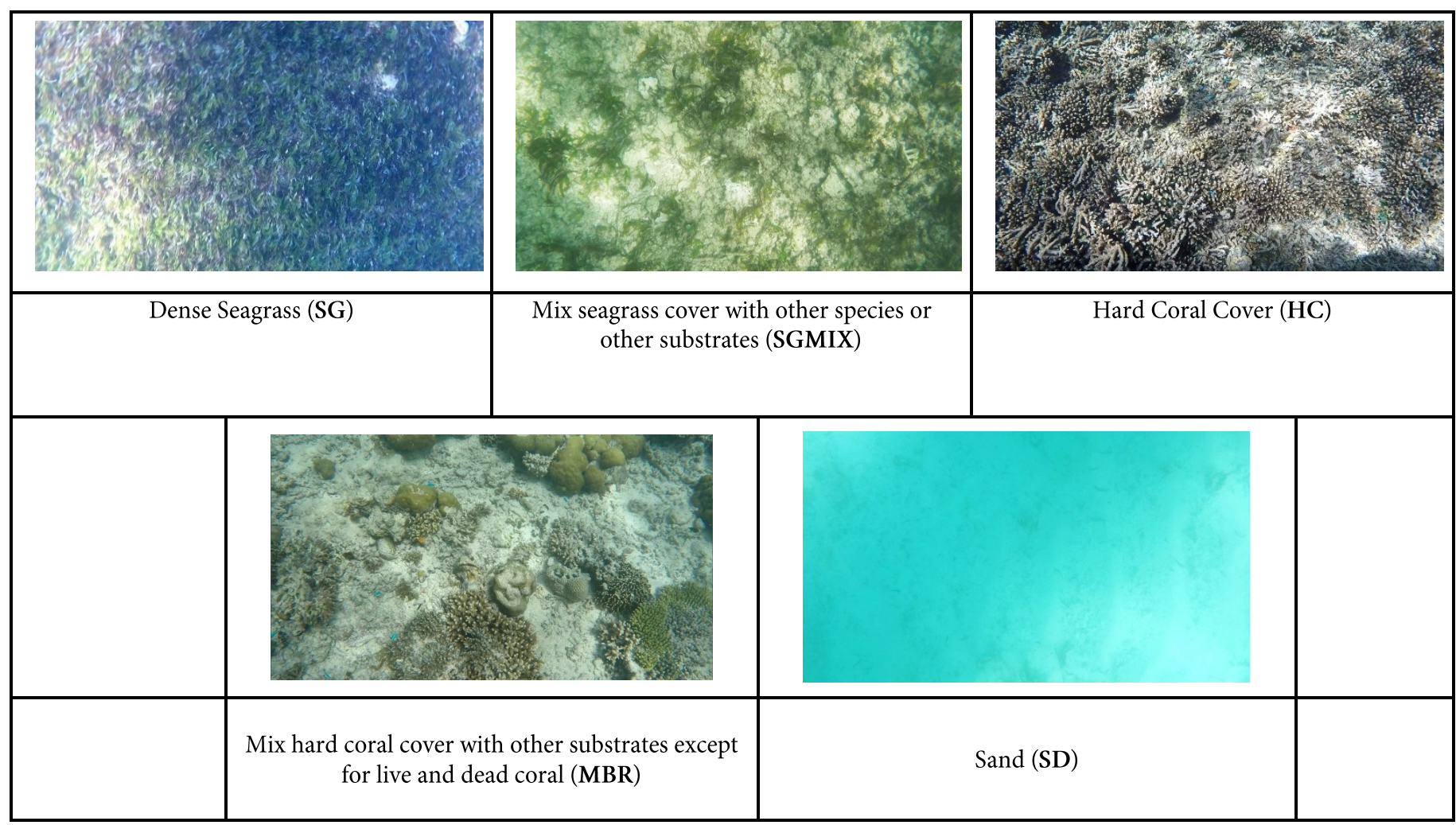

Figure 4. picture of benthic habitat covers in the field

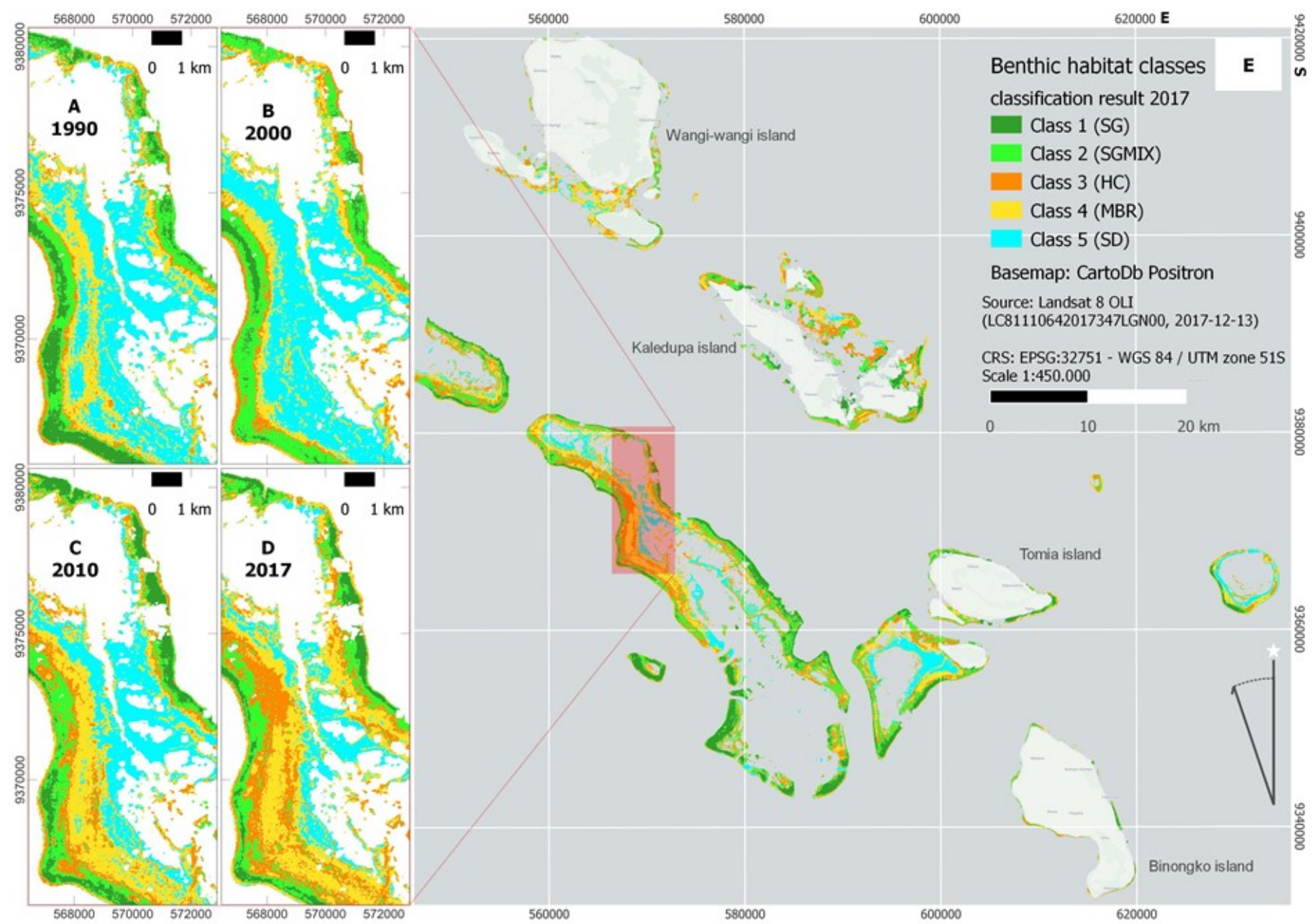

Figure 5. Classification result, A: 1990, B: 2000, C: 2010, D: 2017, E: classification result of Landsat 2017 in Wakatobi Island 
The accuracy of the benthic habitat map, especially the 2017 map in Figure 5E, was 65.35\%. Although the accuracy value was below $80 \%$, which is lower than the reference standard (Lillesand et al., 2015), it still meets the minimum requirement of the Indonesia accuracy standard for a thematic map (60\%) (Badan Informasi Geospatial, 2014). The lower accuracy is due to misclassification between the coral reef and seagrass classes that was difficult to distinguish due to their similar reflectance characteristics (Hochberg et al., 2003). Additionally, the water column correction only minimized the light attenuation effect, which means it still exists although the images have been corrected.

Map accuracy assessment was only applied to the benthic habitat map of 2017 because the other maps (1990, 2000, and 2010) do not have field samples corresponding to the image recording date. Applying the same level of image correction to all images has made the images' quality relatively similar. It means that the noise from atmospheric effect, water surface, and water column attenuation has been minimized, so the pixel values and reflectance pattern on all images representing benthic habitat objects should have nearly similar values for the same objects.

On the other hand, the change detection model that uses the subtractive model produced new bands from 2017's and 1990 's images. It consisted of the NDVI band, ratio red-blue band, and man-made index (Unsalan \& Boyer, 2004). All bands were classified using unsupervised classification, and one of the classes represents the most changed area that can be seen in Figure 6a (inside red line polygons). The polygon indicated the loss of hard coral cover and seagrass cover in 2017, where the two objects were still in good condition 26 years ago (1990). The total area experiences changes from 1990 until 2017 was 3382.83 ha, and the most expansive changed area was on the west side of Kaledupa reef island.

Next, the polygons in figure $6 a$ were used as masking areas in the image classification process to produce a more specific benthic map for particular areas. The masking process was applied to all benthic habitat maps to compare changes on each benthic habitat class from 1990 to 2017 (Figure 6b). For example, in figure 6a, seagrass covers changed into two classes decreasing from 1333.9 hectares to 0.81 hectares to SG class and from 932.7 hectares to 228.3 hectares to SGMIX class. Moreover, the decreasing trend in seagrass cover was $-32.6 \%$ for SGDS class and $-6.4 \%$ for SGMIX class. Decreasing seagrass cover was followed by increasing mix-cover (MBR) and sand (SD) classes. Both classes were initially covered by seagrass in 1990 and then gradually disappeared until they became the existing class in 2017. On the contrary, coral reef cover (HC) increased from 932.7 hectares in 1990 to 1262.7 hectares in 2017.

Integration of all the time-series benthic habitat maps in Figure 5, especially inside the polygons in Figure 6a, produced 25 new classes, as shown in Figure 7. The graph in Figure 7 shows changes in each benthic habitat class every ten years from 1990 until 2010. To allow for more detailed analysis, the 25 new classes were then divided into four

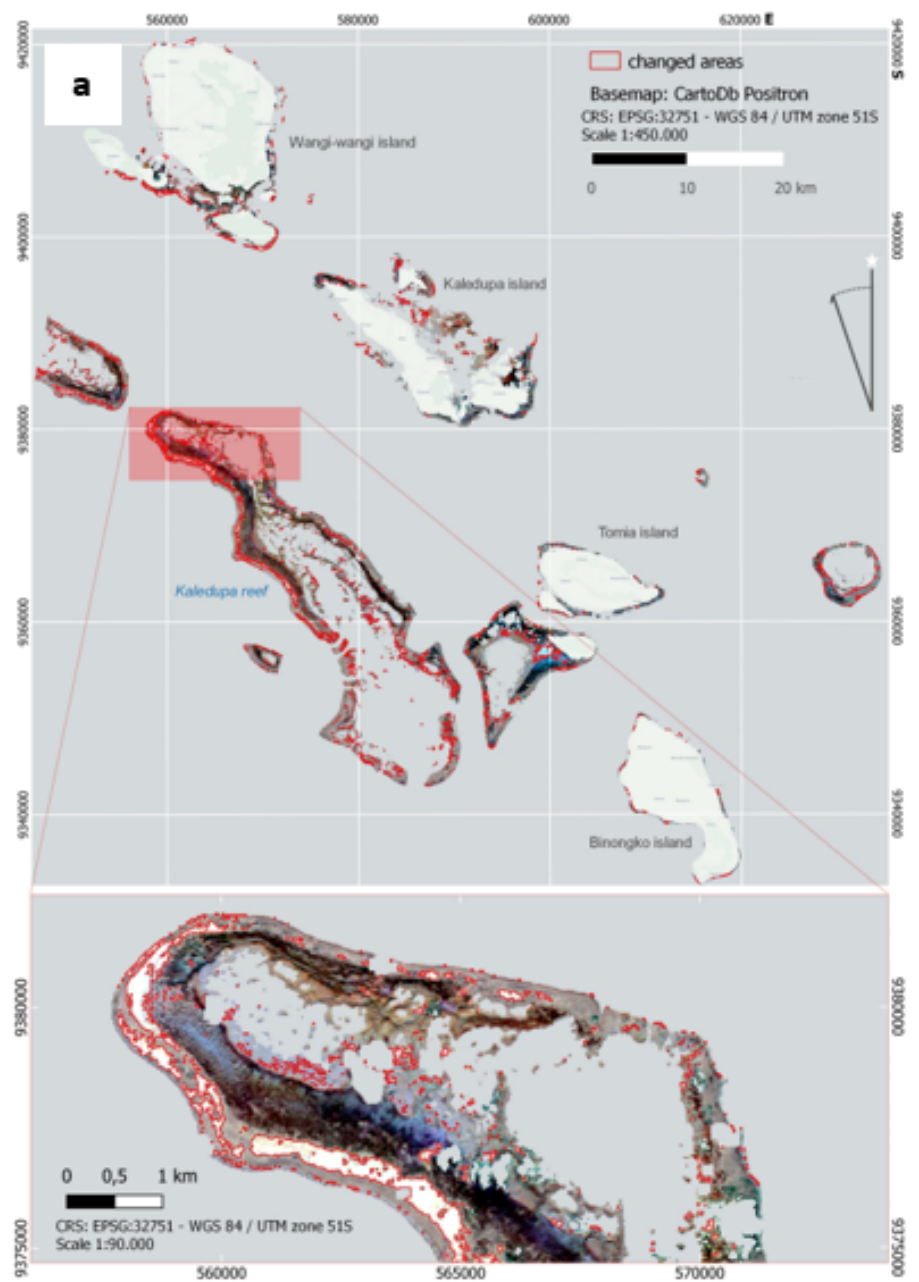

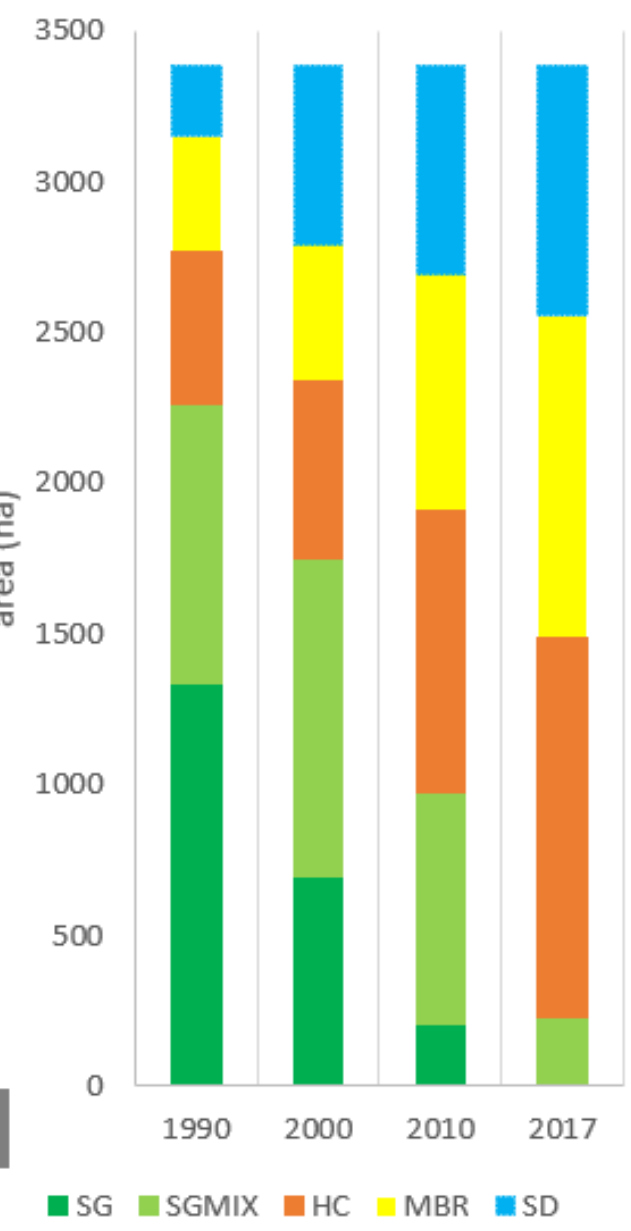

Figure 6. change detection model result, composite 321 (NDVI band, red/blue ratio, 'man-made' index) 


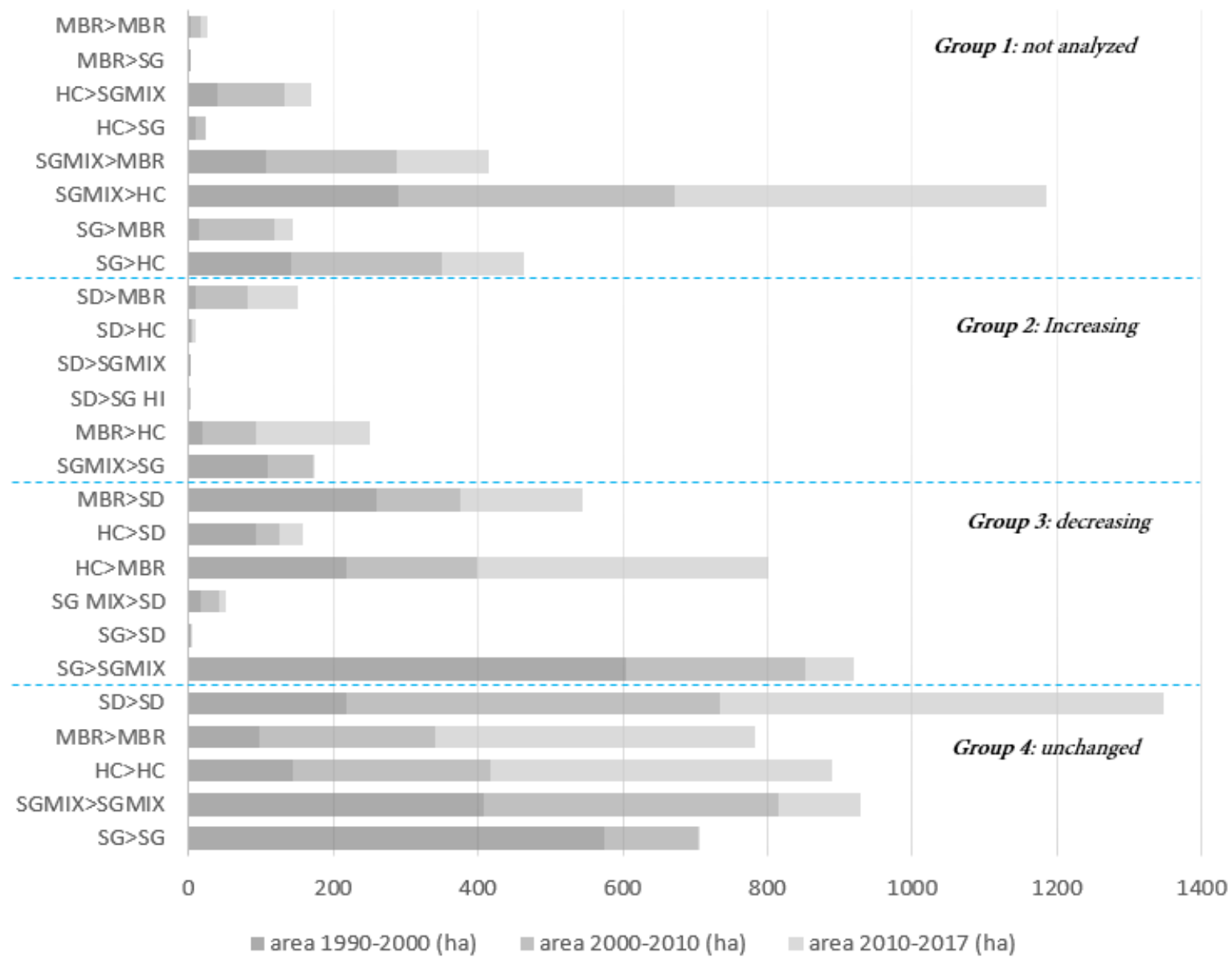

Figure 7. Graph of changing of benthic habitat covers and the area in every ten years from 1990 until 2017

groups, namely not analyzed (group 1), increasing (group 2), decreasing (group 3), and unchanged (group 4).

The change categorized as group 1 was excluded from the analysis as it is almost impossible that the coral reef class changed into seagrass cover or vice versa. As this research focuses on the change of the two essential ecosystems, namely coral reefs, and seagrasses, group 2 was then classified as increasing, and group 3 was classified as decreasing. The increasing group means that coral reefs (HC and MBR) or seagrass (SG and SGMIX) appear and expand in particular areas every ten years. This category includes, for example, sand class (SD) with no seagrass cover or coral reef cover turns into MBR class, which contains a few coral covers. Similarly, the MBR class turns into HC due to expanding coral reef cover from small coverage into full coverage. However, an exception applies to the SGMIX turning into SG class in group 2. Even though the changes from sparse to dense in that class (SGMIX> SG) occurs, the changed areas continue to decrease every ten years.

The decreasing condition of Group 3 was the opposite of group 2. In this group, areas with a high coral reef or seagrass cover changed into low-density classes (SGMIX or MBR) until they changed into bare sand cover (SD). For instance, the $\mathrm{HC}>\mathrm{MBR}$ class and the MBR> SD class experience significant changes. The HC>MBR class changed from coral reefs cover to mix bare substratum cover (e.g., sand, rubble, or rock). It can be said that coral cover continued to decrease every ten years until 2017. In the first ten years (1990 to 2000), the class of HC that changed to MBR class was 217.9 hectares. This decreasing trend continued from 2010 to 2017, with a loss of 402.66 hectares. However, although 2000-2010 shows a decrease in the same places, the increase in the next ten years was significant since 1990.

The last group was Group 4, called the 'unchanged' group, because the classes remain even though the habitat extent keeps changing. Group 4 can be categorized as benthic habitat class, which experiences no changes in the benthic classes. This group experienced an increase in coral cover from 1990 to 2017, but seagrass cover decreased over the same period. The analysis also shows that sand cover (SD) increased drastically from 1990 until 2017. The increase was 219.2 hectares from 1990 to 2000, became 514.1 hectares in 2000, and finally reached 613.6 hectares in 2017.

Other information that came up from integrating the time-series benthic habitat maps was the distribution of the changed classes in the study area, as shown in Figure 8. Two selected areas show the expansion of coral reef area (Figure 9a) and the degradation of seagrass area (Figure 9b) every ten years. The color gradation on the map in Figure 8 shows changes from brighter to darker colors, indicating the location of coral reefs and seagrasses every ten years. A large seagrass area from 1990 to 2000 decreased throughout 2000 to 2010 and almost completely lost in 2017. Therefore, the seagrass cover was the most widely undergone change from 1990 until 2017, particularly on the west side of the Kaledupa Reef (Figure 9b). On the contrary, the coral reef cover in Figure 8a only slightly changed from 1990 to 2000 and expanded significantly until 2017.

Overall, seagrass in Wakatobi islands has decreased significantly from 1990 until 2017. Based on the seagrass monitoring program conducted by Research Center for Oceanography (RCO) Indonesia in 2017 and 2018, the 


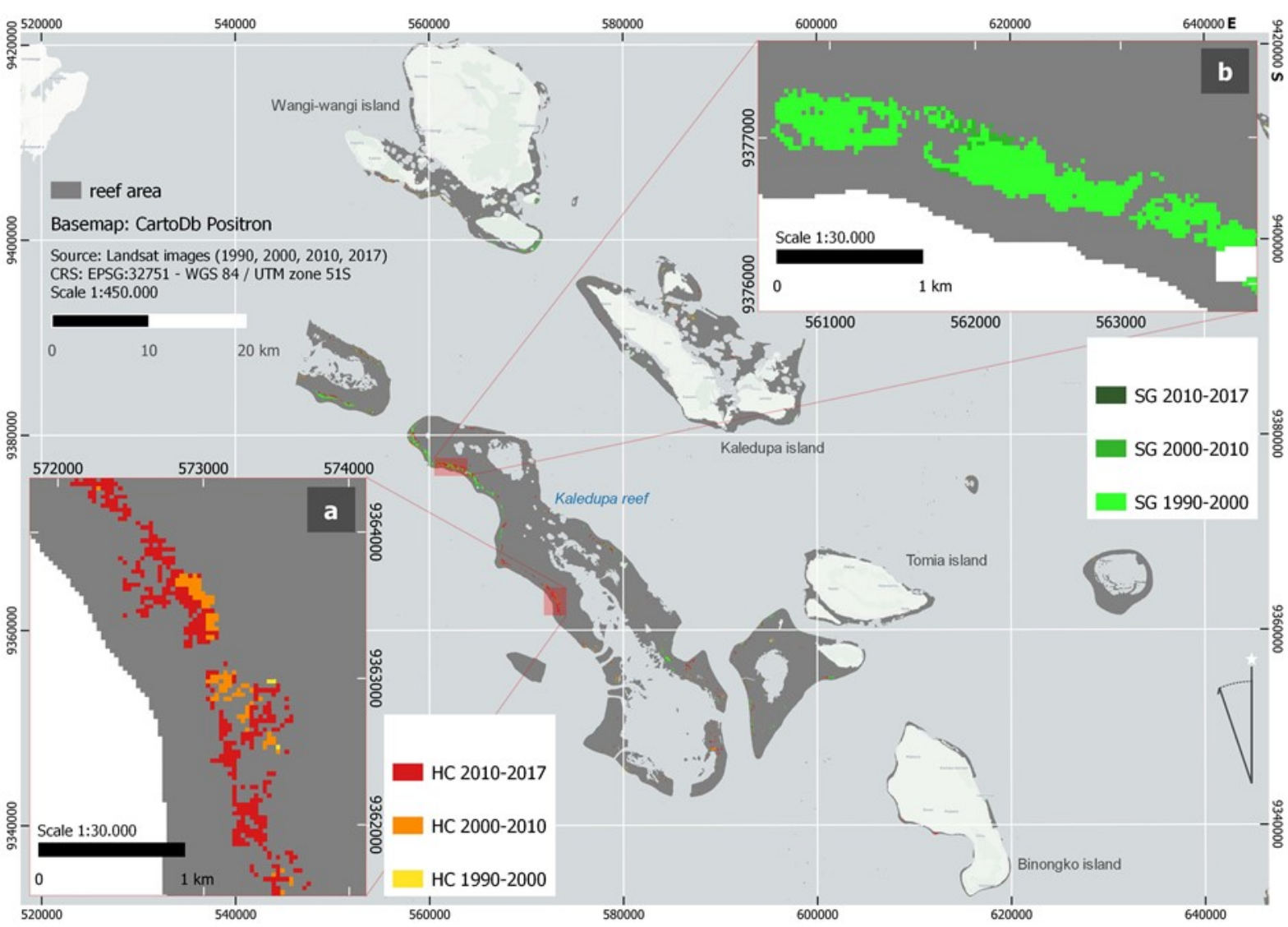

Figure 8. Degradation area of coral reef in every ten years (a), degradation area of seagrass in every ten years (b)

seagrass status was classified as 'unhealthy' (Sjafrie et al., 2018). It means the seagrass cover in the quadrat transect measurement was only 39-59\%. At the same time, coral reef cover shows an increasing trend, although the status was still classified as 'sufficient' in 2017 (Giyanto et al., 2017), and it became the 'poor' category in 2018 (Hadi et al., 2018).

Regarding changes in coral reefs, two things might cause the differences between this study result and the status from the RCO report. First, this study only calculated the changes until 2017, which is different from the RCO report that calculated the status of coral reef at one year period. Second, RCO measures the percentage of healthy coral cover in specific and limited areas using the Underwater Photo Transect (UPT) method (Giyanto et al., 2014). Conversely, this study calculated the changing area for whole reef areas using satellite images without considering the percentage of healthy coral against other benthic types in the field. Therefore, it was reasonable when the results of this study showed the increasing coral reef area extent while the status was relatively poor.

When a restoration program is needed to rehabilitate coral reef and seagrass habitat in Wakatobi islands, the potential restoration location can be determined based on image analysis shown in Figure 8. Coral reef and seagrass class locations that survived from 1990 until 2017 can be designated as protected areas to prevent further degradation. While the areas of coral reefs and seagrass that only survived until 2000 or 2010 can be designated as restoration areas to rehabilitate the habitats (New Heaven Reef Conservation Program, 2016; Thorhaug, 1985). Coral reef and seagrass areas that survived until 2017, mainly on the west side of Kaledupa Reef, can be assigned as a 'no-take zone' in the Marine Protected Area (MPA) program (The Reef Resilience Network, 2014; WWF Indonesia, 2007).

\section{Conclusion}

The study demonstrates that the change detection model (CDM) can better identify specific areas that have experienced significant changes in benthic classes for nearly 30 years. The total changed area identified from the study was 3382.83 hectares, mainly located inside the area experiencing a significant decrease in seagrass cover but an increasing trend in coral cover from 1990 to 2017. Further research is needed to address the potential cause of changes in benthic habitat cover that occurred over almost 30 years by adding the analysis of water quality data (e.g., sea surface temperature and water clarity) or land cover change as the potential factors that affect benthic ecosystems in Wakatobi Islands. Finally, the coral reef and seagrass areas that survived until 2017 can be recommended as protected areas, while coral reef and seagrass areas that only survived until 2000 or 2010 can be designated as restoration areas.

\section{Acknowledgment}

All sample used in this research is from Reef Health Monitoring (RHM) Program by COREMAP-CTI and Research Center for Oceanography (RCO) LIPI. We also thank the RHM coordinator and its members of the Wakatobi team survey (2015 - 2018), who has invited the authors to collect the fields sample for several years.

\section{References}

Anggoro, A., Siregar, V. P., \& Agus, S. B. (2016). The Effect of Sunglint on Benthic Habitats Mapping in Pari Island Using Worldview-2 Imagery. Procedia Environmental Sciences, 33, 487-495. https://doi.org/10.1016/j.proenv.2016.03.101

Badan Informasi Geospatial. (2014). Peraturan Kepala Badan Informasi Geospasial: Pedoman Teknis Pengumpulan dan Pengolahan Data Geospasial Habitat Dasar Perairan Laut Dangkal (B. I. Geospasial (ed.)). http://jdih.big.go.id/laws/4655 
Danoedoro, P. (2012). Pengantar Penginderaan Jauh Digital. Andi Offset.

DJPRL KKP, \& Direktorat PRL-KKP. (2012). Data Kawasan Konservasi Taman Nasional Laut Wakatobi. http:// kkji.kp3k.kkp.go.id/index.php/basisdata-kawasan-konservasi/ details/1/12

Giyanto, Abrar, M., Tri Hadi, A., Budiyanto, A., Hafizt, M., Salatalohy, A., \& Iswari, M. Y. (2017). Status Terumbu Karang Indonesia 2017.

Giyanto, Manuputty, A., Abrar, M., Siringoringo, R., Suharti, S., Wibowo, K., Edrus, I., Arbi, U., Cappenberg, H., Sihaloho, H., Tuti, Y., \& Zulfianita, D. (2014). Panduan Monitoring Kesehatan Terumbu Karang (Suharsono \& O. Sumadhiharga (eds.)). COREMAP CTI LIPI. http://www.coremap.or.id

Goodman, J., Purkis, S., \& Phinn, S. (2013). Coral Reef Remote Sensing: A Guide for Mapping, Monitoring and Management. Springer. https://doi.org/10.1007/978-90-481-9292-2

Green, E., Mumby, P., Edwards, A., \& Clark, C. (2000). Remote Sensing Handbook for Tropical Coastal Management (A. J. Edwards (ed.)). The United Nations Educational, Scientific and Cultural Organization.

Hadi, T. A., Giyanto, Prayudha, B., Hafizt, M., Budiyanto, A., \& Suharsono. (2018). Status Terumbu Karang Indonesia 2018. 30.

Hafizt, M., Manessa, M. D. M., Adi, N. S., \& Prayudha, B. (2017). Benthic Habitat Mapping by Combining Lyzenga's Optical Model and Relative Water Depth Model in Lintea Island, Southeast Sulawesi. IOP Conference Series: Earth and Environmental Science, 98(1), 012037. https:// doi.org/10.1088/1755-1315/98/1/012037

Hafizt, Muhammad, \& Danoedoro, P. (2015). Kajian Pengaruh Koreksi Kolom Air pada Citra Multispektral Worldview-2 untuk Pemetaan Habitat Bentik di Pulau Kemujan Kepulauan Karimunjawa Kabupaten Jepara. In C. Ita, M. Setyardi P, S. Ahmad, Y. Dipo, \& Y. Fajar (Eds.), Kongres VI MAPIN 2015 (p. 566). MAPIN JABODETABEK.

Hafizt, Muhammad, Iswari, M. Y., \& Prayudha, B. (2017). Assessment of Landsat-8 Classification Method for Benthic Habitat Mapping in Padaido Islands, Papua. Oseanologi Dan Limnologi Di Indonesia, 2(1), 1-13. http://jurnal-oldi.or.id/ index.php/oldi/article/view/69

Hernawan, U. E., Sjafrie, N. D., Supriyadi, I. H., Suyarso, Iswari, M. Y., Angraini, K., Rahamt, Eko, U., Nurul, H., Sjafrie, D. M., Supriyadi, I. H., Marindah, S., Kasih, Y. I., \& Rahmat, A. (2017). Status Padang Lamun Indonesia 2017. Puslit Oseanografi - LIPI. http://oseanografi.lipi.go.id/haspen/booklet status lamun 2017.pdf

Hochberg, E. J., Atkinson, M. J., \& Andréfouët, S. (2003). Spectral reflectance of coral reef bottom-types worldwide and implications for coral reef remote sensing. Remote Sensing of Environment, 85(2), 159-173. https://doi.org/10.1016/S00344257(02)00201-8

Joyce, K. E., Phinn, S. R., Roelfsema, C. M., Neil, D. T., \& Dennison, W. C. (2004). Combining Landsat ETM+ and Reef Check classifications for mapping coral reefs: a critical assessment from the southern Great Barrier Reef, Australia. Coral Reefs, 23(1), 21 -25. https://doi.org/10.1007/s00338-003-0357-7

Kay, S., Hedley, J. D., \& Lavender, S. (2009). Sun Glint Correction of High and Low Spatial Resolution Images of Aquatic Scenes: a Review of Methods for Visible and Near-Infrared Wavelengths. Remote Sensing, 1(4), 697-730. https://doi.org/10.3390/ rs 1040697

Lillesand, T. M., Kiefer, R. W., \& Chipman, J. W. (2015). Remote sensing and image interpretation. https://books.google.co.id/ books?

$\mathrm{id}=$ AFHDCAAAQBAJ\&printsec $=$ frontcover\&dq=lillesand + and +kiefer\&hl=en\&sa $=$ X\&ved $=0$ ahUKEwiDz6Wms4rlAhVOk3AK

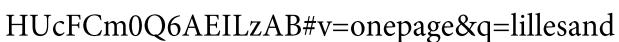

and kiefer\&f=false

LSDS-1574 V1. (2015). LANDSAT 8 (L8) Data Users Handbook (K. Zanter (ed.)). Department of the Interior U.S. Geological Survey.
Lyons, M., Phinn, S., \& Roelfsema, C. (2011). Integrating Quickbird Multi-Spectral Satellite and Field Data: Mapping Bathymetry, Seagrass Cover, Seagrass Species and Change in Moreton Bay, Australia in 2004 and 2007. Remote Sensing, 3(12), 42-64. https://doi.org/10.3390/rs3010042

Manessa, M., Kanno, A., Sekine, M., Ampou, E., Widagti, N., \& Assyakur, A. (2014). Shallow-Water Benthic Identification Using Multispectral Satellite Imagery: Investigation on the Effects of Improving Noise Correction Method and Spectral Cover. Remote Sensing, 6(5), 4454-4472. https://doi.org/10.3390/ rs6054454

New Heaven Reef Conservation Program. (2016). Reef Restoration Methods. https://newheavenreefconservation.org/learningresources/explore-topics/reef-restoration-methods

Nybakken, J. W., \& Eidman, H. M. (1988). Biologi laut $\mathbb{\text { : }}$ suatu pendekatan ekologis. PT Gramedia Pustaka Utama.

Prayudha, B. (2014). Pemetaan Habitat Dasar Perairan Laut Dangkal (Suyarso (ed.)). COREMAP CTI LIPI. http:// www.coremap.or.id

Purkis, S. J., \& Klemas, V. (2011). Remote sensing and global environmental change. Wiley-Blackwell.

Roelfsema, C., \& Phinn, S. (2009). A Manual for Conducting Georeferenced Photo Transects Surveys to Assess the Benthos of Coral Reef and Seagrass Habitats (3rd ed.). Centre for Remote Sensing \& Spatial Information Science School of Geography, Planning \& Environmental Management University of Queensland.

Sjafrie, N. D. M., Hernawan, U. E., Prayudha, B., Supriyadi, I. H., Iswari, M. Y., Rahmat, Anggraini, K., Rahmawati, S., \& Suyarso. (2018). Status Padang Lamun Indonesia ver.02. Puslit Oseanografi - LIPI. http://oseanografi.lipi.go.id/hasilpenelitian/ lihatpdf $/ 38$

The Reef Resilience Network. (2014). Indonesia - MPA Management / Reef Resilience. http://reefresilience.org/casestudies/indonesia-mpa-management/

Thorhaug, A. (1985). Large-scale seagrass restoration in a damaged estuary. Marine Pollution Bulletin, 16(2), 55-62. https:// doi.org/10.1016/0025-326X(85)90124-9

U.S. Department of the Interior. (2019). Landsat Satellite Missions. https://www.usgs.gov/land-resources/nli/landsat/landsatsatellite-missions?qt-science_support_page_related_con=2\#qtscience_support_page_related_con

Unsalan, C., \& Boyer, K. L. (2004). A system to detect houses and residential street networks in multispectral satellite images. Proceedings of the 17th International Conference on Pattern Recognition, 2004. ICPR 2004., 49-52 Vol.3. https:// doi.org/10.1109/ICPR.2004.1334466

USGS. (1879). EarthExplorer. U.S. Department of the Interior U.S. Geological Survey. http://earthexplorer.usgs.gov

Wicaksono, P. (2016). Improving the accuracy of Multispectralbased benthic habitats mapping using image rotations: the application of Principle Component Analysis and Independent Component Analysis. European Journal of Remote Sensing, 49, 433-463. https://doi.org/10.5721/EuJRS20164924

WWF Indonesia. (2007). ZONASI BARU TN WAKATOBI / WWF Indonesia. https://www.wwf.or.id/?2723

Yasir Haya, L. O. M., \& Fujii, M. (2017). Mapping The Change of Coral Reefs Using Remote Sensing and In Situ Measurements: A Case Study in Pangkajene and Kepulauan Regency, Spermonde Archipelago, Indonesia. Journal of Oceanography, 1-23. https://doi.org/10.1007/s10872-017-0422-4 